\title{
Amyloid precursor protein glycosylation is altered in the brain of patients with Alzheimer's disease
}

\author{
Claudia P. Boix ${ }^{1,2 \dagger}$, Inmaculada Lopez-Font ${ }^{1,2,3^{*}+}$, Inmaculada Cuchillo-Ibañez ${ }^{1,2}$ and Javier Sáez-Valero ${ }^{1,2,3^{*}}$ (D)
}

\begin{abstract}
Background: The amyloid precursor protein (APP) is a transmembrane glycoprotein that undergoes alternative proteolytic processing. Its processing through the amyloidogenic pathway originates a large SAPP $\beta$ ectodomain fragment and the $\beta$-amyloid peptide, while non-amyloidogenic processing generates SAPPa and shorter nonfibrillar fragments. Hence, measuring SAPPa and SAPP $\beta$ has been proposed as a means to identify imbalances between the amyloidogenic/non-amyloidogenic pathways in the brain of Alzheimer's disease (AD) patients. However, to date, no consistent changes in these proteolytic fragments have been identified in either the brain or cerebrospinal fluid of AD individuals.

Methods: In frontal cortex homogenates from AD patients $(n=7)$ and non-demented controls (NDC; $n=7)$, the expression of total APP mRNA and that of the APP isoforms generated by alternative splicing, APP695 and APP containing the Kunitz protease inhibitor (KPI), was analyzed by qRT-PCR using TaqMan and SYBR Green probes. The balance between the amyloidogenic/non-amyloidogenic pathways was examined in western blots estimating the SAPPa and SAPP $\beta$ fragments and their membrane-tethered C-terminal fragments CTFa and CTF $\beta$. CHO-PS70 cells, stably over-expressing wild-type human APP, served to evaluate whether A 342 peptide treatment results in altered APP glycosylation. We determined the glycosylation pattern of SAPPa and SAPP $\beta$ in brain extracts and CHO-PS70 culture media by lectin-binding assays.
\end{abstract}

Results: In the cortex of AD patients, we detected an increase in total APP mRNA relative to the controls, due to an increase in both the APP695 and APP-KPI variants. However, the SAPPa or SAPP $\beta$ protein levels remained unchanged, as did those of CTFa and CTF $\beta$. We studied the glycosylation of the brain SAPPa and SAPP $\beta$ using lectins and pan-specific antibodies to discriminate between the fragments originated from neuronal APP695 and $\mathrm{glial} / \mathrm{KPI}$ variants. Lectin binding identified differences in the glycosylation of sAPP $\beta$ species derived from the APP695 and APP-KPI variants, probably reflecting their distinct cellular origin. Moreover, the lectin-binding pattern differed in the SAPPa and SAPP $\beta$ originated from all the variants. Finally, when the lectin-binding pattern was compared between AD and NDC groups, significant differences were evident in SAPPa glycosylation. Lectin binding of the soluble SAPPa and SAPP $\beta$ from CHO-PS70 cells were also altered in cells treated with the AB peptide.

(Continued on next page)

\footnotetext{
*Correspondence: ilopez@umh.es; j.saez@umh.es

${ }^{\dagger}$ Claudia P. Boix and Inmaculada Lopez-Font contributed equally to this work.

'Instituto de Neurociencias de Alicante, Universidad Miguel Hernández-CSIC, Av. Ramón y Cajal s/n, E-03550 Sant Joan d'Alacant, Spain

Full list of author information is available at the end of the article
}

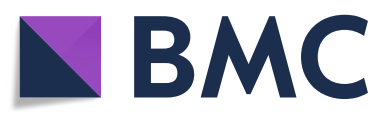

(c) The Author(s). 2020 Open Access This article is licensed under a Creative Commons Attribution 4.0 International License, which permits use, sharing, adaptation, distribution and reproduction in any medium or format, as long as you give appropriate credit to the original author(s) and the source, provide a link to the Creative Commons licence, and indicate if changes were made. The images or other third party material in this article are included in the article's Creative Commons licence, unless indicated otherwise in a credit line to the material. If material is not included in the article's Creative Commons licence and your intended use is not permitted by statutory regulation or exceeds the permitted use, you will need to obtain permission directly from the copyright holder. To view a copy of this licence, visit http://creativecommons.org/licenses/by/4.0/ The Creative Commons Public Domain Dedication waiver (http://creativecommons.org/publicdomain/zero/1.0/) applies to the data made available in this article, unless otherwise stated in a credit line to the data. 
(Continued from previous page)

Conclusion: Our analysis of the lectin binding to SAPPa and SAPP $\beta$ suggests that glycosylation dictates the proteolytic pathway for APP processing. Differences between the demented and controls indicate that changes in glycosylation may influence the generation of the different APP fragments and, consequently, the pathological progression of AD.

Keywords: Alzheimer's disease, sAPPa, sAPPß, Brain, Glycosylation

\section{Introduction}

The major constituent of amyloid plaques is the $\beta$ amyloid $(A \beta)$ peptide, which is thought to be the main pathological effector of Alzheimer's disease (AD). $A \beta$ is a polypeptide generated by proteolytic processing of the much larger amyloid precursor protein (APP), a ubiquitous glycoprotein expressed strongly throughout the brain. APP is a type I transmembrane protein that resembles a cell surface receptor, containing a large N-terminal ectodomain, a transmembrane domain that contains part of the $A \beta$ sequence, and a short intracellular $\mathrm{C}$-terminal domain [31]. APP is processed through the successive action of enzymes known as secretases, undergoing alternative proteolytic processing (reviewed in [2]). Thus, sequential processing of APP always commences with the cleavage of the ectodomain by the secretase sheddase, which acts at residues close to the transmembrane domain to generate a large N-terminal fragment (NTF). In the amyloidogenic pathway, APP cleavage by $\beta$-secretase results in the secretion of an exclusive NTF, sAPP $\beta$. This pathway co-exists with the so-called non-amyloidogenic pathway that is initiated by $\alpha$-secretase cleavage within the $A \beta$ domain, precluding $A \beta$ formation and resulting in the secretion of the sAPP $\alpha$ NTF. Subsequently, the membrane-tethered Cterminal fragments that remain, the CTF $\beta$ (99 amino acids, the so-called C99) and CTF $\alpha$ (83 amino acids, C83), are cleaved at the boundaries of the lipid bilayer by $\gamma$ secretase, releasing the extracellular $A \beta$ (amyloidogenic pathway) or a short non-amyloidogenic peptide named $\mathrm{p} 3$, as well as a soluble fragment known as the intracellular domain (ICD; reviewed in [43]). Alternatively, $\beta$-secretase can cleave APP at Glu11 in the A $\beta$ sequence, generating a 89 amino acids CTF $\beta$ (C89) that will be further processed by $\gamma$-secretase to generate a N-terminally truncated $A \beta 11-x$ species [61].

The currently prevailing idea is that an excess of soluble $A \beta$ oligomers becomes neurotoxic and can trigger the onset of AD. However, while the amount of pathological $A \beta$ species are expected to increase in the $A D$ brain (particularly the $A \beta 42$ ), these $A \beta 42$ peptides are rapidly trapped into plaques. As such, it is quite a challenge to monitor the soluble $A \beta$ in cerebrospinal fluid (CSF) as a read-out of any possible disturbance to APP amyloidogenic/non-amyloidogenic processing, or of the enhanced generation of $A \beta$ in the brain.
Estimating the amount of unprocessed full-length APP in brain homogenates is also a challenge, not least due to the fast recycling of cell-surface APP after endocytosis [60]. Indeed, APP can be constitutively cleaved by secretases, even during its maturation [43]. In this context, CSF levels of sAPP $\alpha$ and sAPP $\beta$ fragments have been evaluated as a tool to detect the equilibrium between the non-amyloidogenic and amyloidogenic processing of APP, although no consistent changes have as yet been reported $[45,49]$. A few studies have analyzed possible alterations to the levels of sAPP $\alpha$ or sAPP $\beta$ in AD patient brain homogenates [37, 72], or changes in CTF $\alpha$ and $\operatorname{CTF} \beta[47,51,52]$, yet again with inconclusive results.

Significantly, APP undergoes alternative splicing and the significance of different APP variants in particular cell types may reflect its distinct physiological roles. These variants may also have different regulatory requirements and respond differently to pathological changes, highlighting the need for them to be fully characterized. Alternative splicing generates APP transcripts of different sizes and while the primary isoform expressed in neurons is the socalled APP695 isoform (the number indicating the amino acid residues encoded), the longer APP751 variant is mainly expressed in astrocytes and other glial cells. This longer APP variant harbors an amino acid insert in its extracellular domain that is homologous to a Kunitz-type serine protease inhibitor (KPI). Another long isoform is APP770, which is widely expressed in peripheral tissues but minimally in the brain, and that also contains the KPI domain as well as an additional domain with homology to the MRC OX-2 antigen [10, 38]. Currently, the regarding APP mRNA expression in the brain of $A D$ patients is somewhat confusing, with reports of increases [14, 46], no significant change [19], or even decreases in expression $[13,66]$. This puzzling scenario can be extended to specific APP mRNA splice variants, with studies indicating different changes in mRNA encoding the APP695 [28, 30, $46]$ or the APP-KPI variants [50, 64].

Glycosylation plays a critical role in the trafficking and final subcellular localization of many proteins. Newly synthesized APP undergoes various post-translational modifications, including $\mathrm{N}$ - and O-linked glycosylation, and its sequential proteolytic processing, either through the amyloidogenic or non-amyloidogenic pathways, occurs 
after glycosylation [67]. Accordingly, the trafficking and final subcellular localization of APP appears to be crucial to determine the proteolytic processing of surface APP, and changes in glycosylation have been related to differences in APP processing, particularly O-glycosylation, [27, $11,34,41,42]$.

Hence, we set out to determine whether APP mRNA expression is altered in the brain of $\mathrm{AD}$ patients. In addition, we characterized and determined the balance of the proteolytic SAPP $\alpha$ and $\operatorname{SAPP} \beta$, and CTF $\alpha$ and CTF $\beta$, fragments in the brain. We also examined whether the patterns of sAPP $\alpha$ and sAPP $\beta$ glycosylation are altered in the brain of $\mathrm{AD}$ subjects and in $\mathrm{A} \beta$-treated cells.

\section{Materials and methods}

This study was approved by the ethics committee at the Miguel Hernandez University, and it was carried out in accordance with the Helsinki Declaration regarding research on humans. Frozen brain samples from 7 AD patients (4 females and 3 males, $81 \pm 12$ years of age) and 7 nondemented control cases (NDC, 4 females and 3 males: $65 \pm 15$ years) were obtained from the Banco de Tejidos Neurológicos, Fundación CIEN-Unidad de Investigación Proyecto Alzheimer (UIPA: Madrid, Spain), and the Biobanco en Red de la Región de Murcia (Biobanc-Mur, Murcia, Spain), both coordinated by the neuropathologist Dr. A. Rábano (Fundación CIEN-UIPA). Cases of sporadic AD were selected based on their clinical history of dementia and a neuropathological CERAD diagnosis [39], and they were categorized as stages V-VI on the Braak and Braak scale [6]. Samples from NDCs corresponded to individuals with no recognized clinical dementia and no evidence of any other brain pathology. The mean postmortem interval of the tissue was between 1.5 and $6 \mathrm{~h}$, with no significant differences between the two groups.

\section{Brain homogenization and extraction}

Samples of human frontal cortex stored at $-80^{\circ} \mathrm{C}$ were thawed gradually at $4{ }^{\circ} \mathrm{C}$ and then homogenized in ice-cold extraction buffer $(10 \% \mathrm{wt} / \mathrm{vol})$ supplemented with a cocktail of proteinase inhibitors (cat\# P834; Sigma Aldrich): $50 \mathrm{mM}$ Tris- $\mathrm{HCl}$ [pH 7.4], $150 \mathrm{mM} \mathrm{NaCl}, 0.5 \%$ Triton X-100, and $0.5 \%$ Nonidet P-40 [5]. The homogenates were sonicated and centrifuged at $100,000 \times g$ and $4{ }^{\circ} \mathrm{C}$ for $1 \mathrm{~h}$, and the supernatant was collected, aliquoted, and frozen at $-80^{\circ} \mathrm{C}$ until use. Total protein concentrations were determined using the bicinchoninic acid method (Pierce).

\section{APP over-expressing cells}

To obtain conditioned cell-culture medium, CHO-PS70 cells stably over-expressing wild-type human APP (APP751) and the $\gamma$-secretase catalytic subunit presenilin-1 [73] were grown for $48 \mathrm{~h}$ in six-well plates $(350,000$ cells/well) in
Dulbecco's modified Eagle's medium (DMEM) plus GlutaMAX $^{\mathrm{ma}}$ (Gibco $^{\circ}$ Life Technologies, Paisley, UK), supplemented with $5 \%$ fetal bovine serum (FBS: Gibco) and $100 \mu \mathrm{g} / \mathrm{mL}$ penicillin/streptomycin (Gibco). To allow APP-CTFs to accumulate, the cells were treated with the $\gamma$-secretase inhibitor DAPT $(5 \mu \mathrm{M}$, LY-374973 (N-[N-(3,5-difluorophenacetyl)-l-alanyl]-Sphenylglycine t-butyl ester: Calbiochem ${ }^{\circ}$, Merck KGaA), as described previously [62]. Control cells were treated with the same volume of the dimethyl sulfoxide (DMSO) vehicle alone. After an $18 \mathrm{~h}$ exposure to the inhibitor, the cells were washed twice with cold phosphate-buffered saline (PBS) and resuspended in $100 \mu \mathrm{L}$ of ice-cold extraction buffer supplemented with a cocktail of protease inhibitors. The cell lysates were sonicated and centrifuged for $1 \mathrm{~h}$ at $70,000 \times g$ and $4{ }^{\circ} \mathrm{C}$, and the extracts were frozen at $-80^{\circ} \mathrm{C}$ for future analysis.

Alternatively, CHO-PS70 cells were treated with A $31-42$ peptide $(\mathrm{A} \beta 42)$ for glycosylation analysis by lectin binding. The $A \beta 1-42$ peptide (A $\beta 42)$ and the scrambled control peptide (AIAEGDSHVLKEGAYMEIFDVQGHVFGGKIFRVVDLGSHNVA) (Anaspec Peptide, Eurogentec) were dissolved in sterilized distilled water at a concentration of $1 \mathrm{mg} / \mathrm{mL}$, aliquoted, and stored at $-80^{\circ} \mathrm{C}$ until use. Suspensions of $A \beta 42$ or the scrambled peptide at a final concentration of $5 \mu \mathrm{M}$ were added to the cells, once a day for 2 days, without changing the cell media. The conditioned medium from each culture dish was removed, centrifuged at $1000 \times g$ at $4{ }^{\circ} \mathrm{C}$ for $5 \mathrm{~min}$, and the supernatant was recovered and stored at $-80^{\circ} \mathrm{C}$ till use.

\section{RNA isolation and $q \mathrm{RT}-\mathrm{PCR}$ analysis of transcripts}

Total RNA was isolated from human brain cortical tissue using the TRIzol Reagent and the PureLink ${ }^{\mathrm{Tm}}$ Micro-toMidi Total RNA Purification System (Invitrogen), following the manufacturer's instructions. First-strand cDNAs were obtained by reverse transcription of this total RNA $(1.5 \mu \mathrm{g})$ using the High Capacity cDNA Reverse Transcription Kit (Applied Biosystems; Life Technologies Paisley, UK), according to the manufacturer's instructions. Quantitative reverse transcription-polymerase chain reactions ( $q$ RT-PCRs) were performed using a StepOne-Plus ${ }^{\text {Tix }}$ RealTime PCR System with the Power SYBR ${ }^{\circ}$ Green PCR Master Mix (Applied Biosystems, Carlsbad, CA, USA), according to the manufacturer's instructions. Primers were designed to analyze the total APP brain transcripts as a whole (forward 5'-AACCAGTGACCATCCAGAAC-3', reverse $5^{\prime}$-ACTTGTCAGGAACGAGAAGG-3'), as well as the APP695 (forward 5'- GGTGGTTCGAGTTCCT ACAA-3', reverse 5' - CCTCTCTTTGGCTTTCTGGA$3^{\prime}$ ) and APP-KPI species (forward 5' - CCCGAGATCC TGTTAAACTTC-3', reverse 5' - CCTCTCTTTGGCTT TCTGG-3') [20]. Commercial primers were obtained for 
the house-keeping human 18S gene (Applied Biosystems, Carlsbad, CA, USA). In addition, $q$ RT-PCR was also performed using TaqMan Gene Expression Assays to amplify the total APP transcripts (Hs00169098-m1 for APP and Hs03003631-g1 for 18S; Thermo Fisher) and the TaqMan PCR Master Mix. Transcript levels were calculated by the comparative $2^{-\Delta \mathrm{Ct}}$ method relative to the $18 \mathrm{~S}$ cDNA.

\section{Western blotting}

Brain extract samples (30 $\mu$ g of protein per lane) were boiled at $95^{\circ} \mathrm{C}$ for $5 \mathrm{~min}$ and resolved by $7.5 \%$ SDSPAGE. The APP species in the samples were detected using: a rabbit polyclonal anti-APP C-terminal antiserum (1:1000; Sigma Aldrich, St. Louis, MO, USA: referred to here as Sigma-Ct); a rat monoclonal antibody named 2D8 raised against the $\mathrm{N}$-terminal domain of $\mathrm{A} \beta$, thus that detects CTF $\beta$ but not CTF $\alpha$ (1:50, [71]), a rabbit polyclonal anti-sAPP $\beta$ antiserum specific to the Cterminus of $\operatorname{sAPP} \beta$ (1:100; IBL, Hamburg, Germany: referred to here as IBL- $\beta$ ); a mouse monoclonal antisAPP $\alpha$ antibody specific to the C-terminus of sAPP $\alpha$ (1: 100; IBL, referred to here as IBL- $\alpha$ ); and a rabbit polyclonal anti-KPI antiserum specific to the KPI domain of APP (1:500; Millipore: referred to here as KPI). The immunoreactive signal from the APP bands was quantified in western blots of the cerebral cortex tissue. Vinculin (1:2000, anti-vinculin mouse monoclonal antibody, sc73614 Santa Cruz; 1:1000, anti-vinculin rabbit antiserum, Sigma V4139) and GAPDH (1:10000, anti-GAPDH mouse monoclonal antibody, Proteintech 60004-1) served as loading controls. Band intensities were analyzed using LI-COR software (Image Studio Lite). Using ELISA assays, the manufacturer estimated that cross-reactivity between the sAPP $\alpha$ and sAPP $\beta$ fragments is less than $1.5 \%$ and that neither antibody cross-reacts with full-length APP. The specificity of these pan-specific sAPP $\alpha$ and sAPP $\beta$ antibodies has also tested been previously in western blots [36]. The blots were probed with the appropriately conjugated secondary antibodies (IRDye 680RD goat anti-mouse; IRDye $800 \mathrm{CW}$ goat anti-rabbit; IRDye 680RD goat anti-rabbit or IRDye $800 \mathrm{CW}$ goat anti-rat: all from LI-COR Biosciences $\mathrm{GmbH}$, Bad Homburg, Germany) and analyzed on an Odyssey Clx Infrared Imaging System (LI-COR).

\section{Lectin binding and an analysis of enzymatic deglycosylation}

Brain extracts and culture media samples were incubated overnight at $4{ }^{\circ} \mathrm{C}$ with lectins specific to terminal sugars immobilized to sepharose or agarose beads: the mannosebinding lectin Con A (from Canavalia ensiformis; Sigma); and the lectin that recognizes more complex type $\mathrm{N}$ glycans, the biantennary galactosylated N-glycan with bisecting $\mathrm{N}$-acetylglucosamine-binding lectin PHA (PHA-L lectin from Phaseolus vulgaris; Vector). The fraction of proteins not linked to lectins was separated by centrifugation and analyzed in western blots probed with antibodies against SAPP $\alpha$ and sAPP $\beta$. The proportion of non-lectinbound APP was calculated as the ratio of non-lectin-bound APP immunoreactivity to the total immunoreactivity, the latter obtained from an aliquot maintained under the same conditions but not incubated with a lectin. All the analyses were carried out in duplicate.

Brain glycoproteins were also assessed using an enzymatic deglycosylation kit from ProZyme (GK80110), following the manufacturer's instructions, and analyzed in western blots. The glycoproteins were deglycosylated with N-Glycanase, O-Glycanase, and Sialidase A following a protocol for full deglycosylation of the proteins. This treatment removes all $\mathrm{N}$-linked and simple $\mathrm{O}$-linked glycans (including polysialylated moietes) from glycoproteins.

\section{Statistical analysis}

All data were analyzed in SigmaStat (Version 2.0; SPSS Inc.), applying a Student's $t$ test (two-tailed) or a MannWhitney $U$ test for determining the exact $p$ values ( $p$ values $<0.05$ were considered significant). The results are presented as the means \pm SEM and the correlation between variables was assessed by linear regression analyses.

\section{Results}

\section{Increased APP expression in the brain of AD subjects}

The expression of total APP was quantified in brain samples from $\mathrm{AD}$ and control subjects by $q \mathrm{RT}-\mathrm{PCR}$, using SYBR Green and primers designed to amplify exon 3, which is common to all APP variants. The overall expression of APP was significantly higher in the AD cortical tissue than in the NDC tissue $(p=0.004$, Fig. 1a). The increase was corroborated when the same samples were re-analyzed using Taqman probes (exons 10-11, common to the major brain variants) for total APP $(p<0.001$ : Supplemental Fig. 1A). The APP expression assessed with the SYBR Green primers and Taqman probes was significantly correlated $(r=0.7, p=0.006)$, as reported for other genes assayed with both techniques $[4,63]$.

To determine whether the increment in total APP mRNA in AD patients corresponds to a particular splice variant, we next analyzed APP695 and APP-KPI variants mRNA expression, using specific primers for SYBR Green. The expression of both, APP695 and APP-KPI, was significantly increased in AD brain respect to that in the control brain (Fig. 1b). This was particularly noticeable for APP-KPI mRNA (2.4 times higher in AD than in control) than for APP695 (2.0 times higher in AD than in control).

\section{Characterization and determination of $s A P P a, s A P P \beta$, $C T F a$, and CTF $\beta$ in the brain of $A D$ subjects}

We next examined the APP proteolytic fragments, sAPP $\alpha$ or sAPP $\beta$, in western blots of the brain tissue 

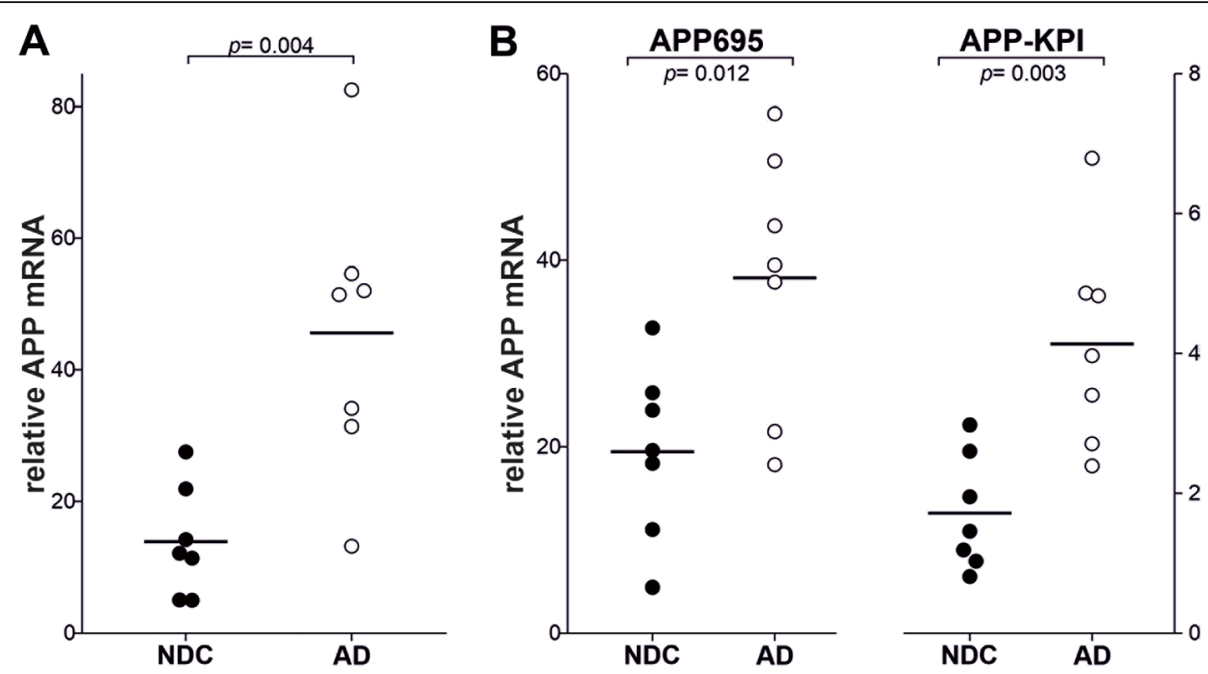

Fig. 1 Increased APP mRNA in the frontal cortex of AD patients. Relative mRNA expression of transcripts for a total APP, and the $\mathbf{b}$ APP-KPI and APP-695 splice variants, analyzed by qRT-PCR in frontal cortex tissue from NDC $(n=7)$ and AD subjects (Braak stages V-VI, $-=7)$. To analyze APP transcripts, specific Power SYBR ${ }^{\oplus}$ Green PCR Master Mix primers were employed and the specificity of the PCR products was confirmed by analyzing the dissociation curves. Transcript levels were calculated by the comparative $2^{-\Delta \mathrm{Ct}}$ method with respect to $18 \mathrm{~S}$ rRNA from the same CDNA and expressed as the mean \pm SEM: $p<0.001$ relative to the NDCs as indicated

from AD subjects, a method that enabled different APP species to be discriminated, especially those with different molecular masses. However, sAPP $\alpha$ or SAPP $\beta$ are predicted to be only $\sim 5-10 \mathrm{kDa}$ smaller than full-length APP, and as such, it is not possible to distinguish these variants by electrophoretic separation [22]. Moreover, small differences in electrophoretic migration may also be attributed to differences in glycosylation [9], or even reflect immature forms of the protein [70]. Accordingly, we discriminated these sAPP $\alpha$ and $\mathrm{sAPP} \beta$ variants using pan-specific antibodies generated against the specific $\mathrm{C}$ terminal domain, antibodies with proven specificity [36].

In previous studies, APP was detected as several bands that migrate between 100 and $130 \mathrm{kDa}[40,59]$. These differences in molecular mass possibly reflect splice variants of the predominant neuronal APP695 and the glial species that included the KPI domain that is indistinguishable in size, i.e., APP751 and APP770. All these variants are subjected to proteolytic processing by secretases and thus, they produce similar sAPP $\alpha$ and sAPP $\beta$. As such, a scheme has been devised that represents the full-length APP, and the NTFs and CTFs generated, with indications of the epitopes recognized by the antibodies used in this study (Fig. 2a). The brain APP-NTF species were characterized with pan-specific antibodies for sAPP $\alpha$ or sAPP $\beta$ (Fig. 2b), but also with an anti-KPI antibody, indicating that only the higher molecular mass bands are sAPP species derived from KPI (see also Supplemental Fig. 2A for a multiplex assay of fluorescence). The additional band of $\sim 100 \mathrm{kDa}$ detected by the anti-KPI antibody might correspond to an immature APP species. We previously observed a band of similar molecular mass in human CSF when simultaneously using antibodies against KPI and the APP N-terminal [36]. Alternatively, because this band was not recognized by sAPP $\alpha$ and sAPP $\beta$ antibodies, it might correspond to the nearest relative of APP, the amyloid precursor-like protein 2 (APLP2), which is also regulated by alternative splicing of the KPI domain [56]. However, further analysis will be required to define the true identity of this band.

Since sAPP $\beta$ and sAPP $\alpha$ share the same sequence except for the last $16 \mathrm{C}$-terminal amino acids, they would not be expected to be distinguished in western blots on the basis of their size. However, when brain extracts were assessed in parallel with sAPP $\alpha$ - and sAPP $\beta$-specific antibodies, differences in molecular mass were evident, particularly for the species derived from APP695 (Fig. 2b, c). These differences were corroborated when western blots were probed simultaneously with these specific sAPP antibodies using multiplex fluorescence imaging (Supplemental Fig. 2B). Conditioned media from $\mathrm{CHO}$ cells over-expressing APP751 (APP-KPI) also indicated that the immunoreactive bands for sAPP $\alpha$ and sAPP $\beta$ did not overlap (Supplemental Fig. 2C).

Treatment with $\mathrm{N}$ - and O-glycosidases that fully deglycosylate APP caused a reduction in the apparent molecular mass of the sAPP $\alpha$ and sAPP $\beta$ fragments derived from APP-KPI, while the shift of SAPP $\alpha$ and sAPP $\beta$ derived from APP695 was less than expected (Fig. 2c). The differences in the electrophoretic mobility between glycosylated and deglycosylated glycoproteins are probably related to the carbohydrate mass but also, to changes in protein shape that affects their migration 


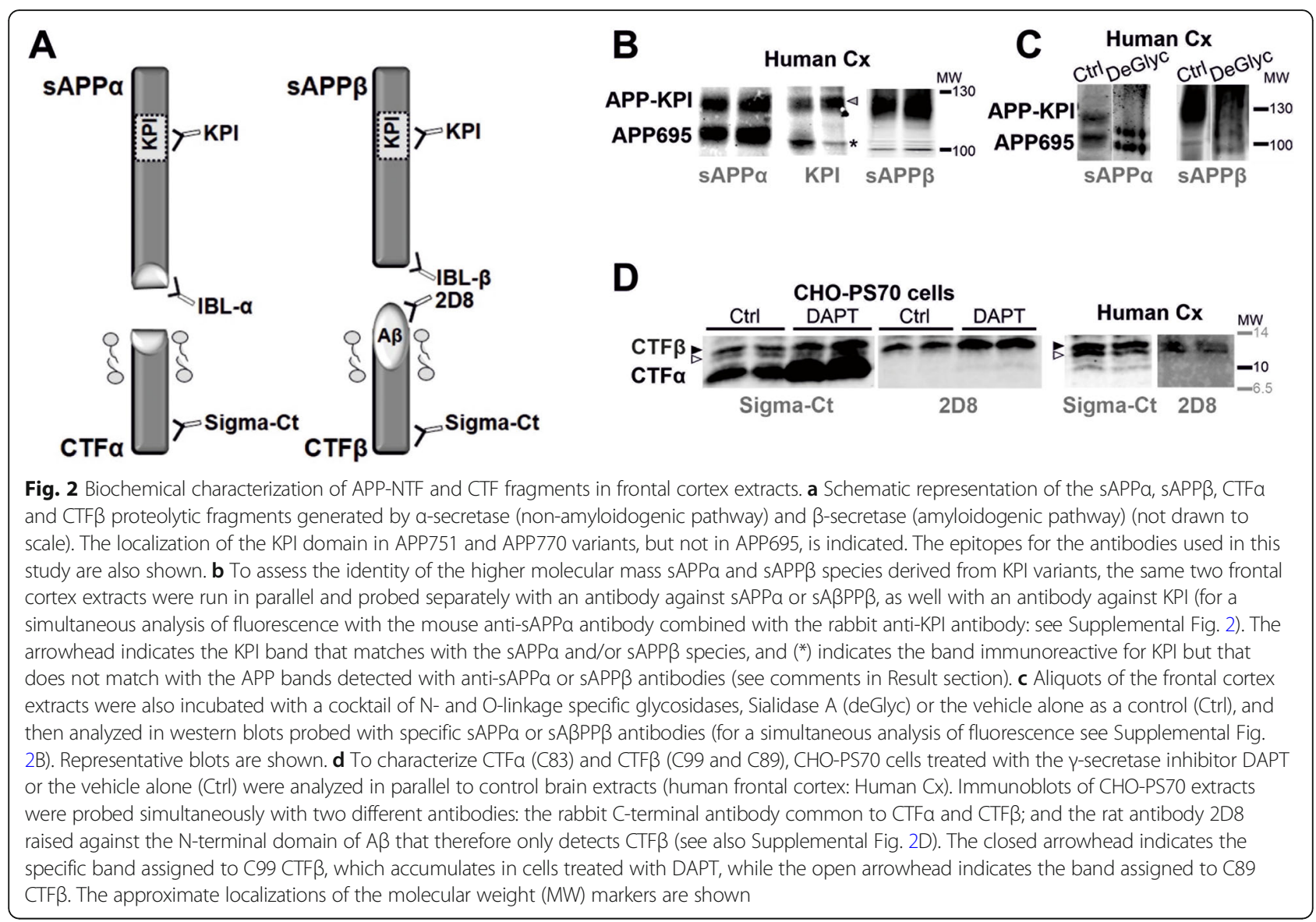

since glycosylated proteins are normally more globular as their carbohydrate chains are not linear, even in reducing conditions. Interestingly, deglycosylated sAPP $\alpha$ and sAPP $\beta$ had a similar molecular mass (Fig. 2c) and even co-localized (Supplemental Fig. 2B, C), suggesting that the differences in the molecular mass observed between native SAPP $\alpha$ and SAPP $\beta$ species are mainly due to differences in their glycosylation.

The CTF $\alpha$ and CTF $\beta$ do not differ between the APP variants, and they were characterized using extracts of CHO-PS70 cells stably overexpressing wild-type human APP and PS1 [73]. Extracts of these cells treated with the $\gamma$-secretase inhibitor DAPT were probed with a Cterminal antibody, providing evidence of the accumulation of CTF $\alpha$ and CTF $\beta$. These bands matched those bands found in brain homogenates loaded in parallel (Fig. 2d). When blots were probed with the rat 2D8 antibody raised against the $\mathrm{N}$-terminal domain of $\mathrm{A} \beta, \mathrm{CTF} \alpha$ and CTF $\beta$ could be discriminated as the epitope recognized by this antibody is absent in CTF $\alpha$ (see scheme in Fig. 2a). Both antibodies resolved the doublet attributed to CTF $\beta$, probably C99 and C89, although the upper band (C99) accumulated more in DAPT-treated cells (Fig. 2d; and Supplemental Fig. 2D for a simultaneous analysis using multiplex fluorescence imaging). Indeed, the $\gamma$-secretase inhibitor was previously seen to provoke an increase in the APP C99/C89 ratio [61], making it plausible that the lower band is APP C89.

After this biochemical characterization, the different sAPP $\alpha$ and sAPP $\beta$ isoforms were assessed in extracts from the human brain cortex. No differences were detected between the NDC and AD samples in the relative levels of sAPP $\alpha$ (Fig. 3a) or sAPP $\beta$ (Fig. 3b) derived from APP695 or APP-KPI. Despite the large differences in the APP695/APP-KPI ratios for the sAPP $\alpha$ and sAPP $\beta$ species, no differences in these ratios were evident between NDC and AD samples (Fig. 3c). The accumulation of sAPP $\alpha-695$ and sAPP $\alpha$-KPI immunoreactive bands was positively correlated in both NDC $(r=0.76 ; p=$ $0.048)$ and $\mathrm{AD}(r=0.96 ; p<0.001)$ tissue extracts, although this correlation was not significant for the SAPP $\beta$ species (NDC: $r=0.19 ; p=0.69$; AD: $r=0.57 ; p=0.17$ ). There were no significant correlations between the immunoreactivity of $\mathrm{sAPP} \alpha$ and $\mathrm{SAPP} \beta$ irrespective of whether they were derived from the APP695 or APP$\mathrm{KPI}$ isoforms, or if the samples were from NDC or AD subjects (Supplemental Fig. 3).

The immunoreactive bands attributed to APP-KPI were also assessed in blots of frontal cortex extracts probed with an antibody raised against the KPI domain. 


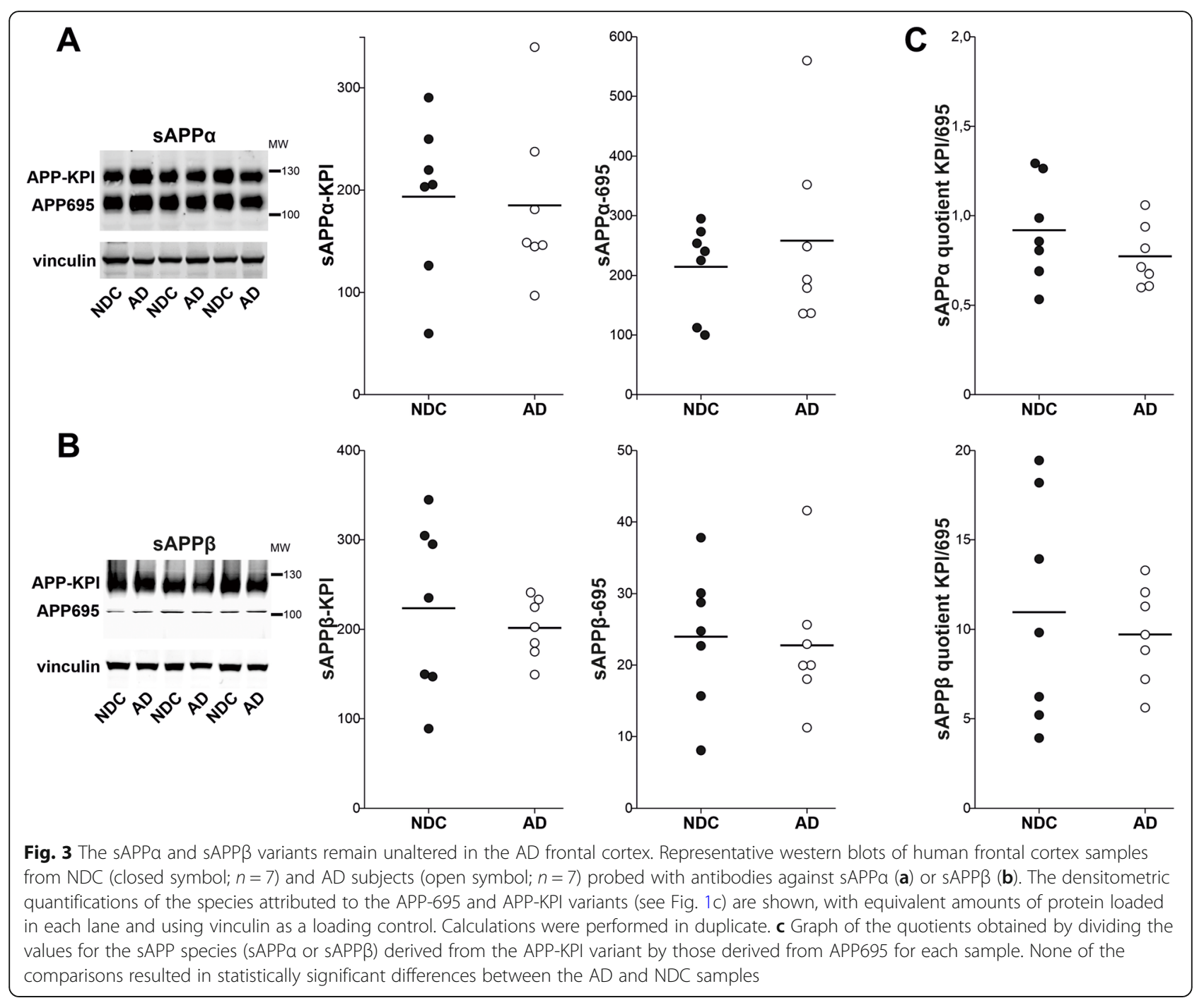

No significant changes were evident in the relative levels of APP-KPI species between AD and NDC subjects (Supplemental Fig. 4). The assignation of the KPIimmunoreactive band as APP-KPI was based on its previous co-localization with the anti-sAPP $\alpha$ antibody (Supplemental Fig. 2A). However, the anti-KPI antibody cannot distinguish between species derived from SAPP $\alpha$ and sAPP $\beta$, or between large NTF fragments and full-length variants, all these species potentially overlapping in terms of their electrophoretic mobility. Thus, our data are only indicative of APP-KPI levels in frontal cortex extracts as a whole.

To assess whether APP-CTF levels were altered in brain extracts from AD patients, we used an antibody raised against the original C-terminal domain of fulllength APP (Fig. 4a). The immunoreactivity for brain CTFß (C99 and C89: Fig. 4b) and CTF $\alpha$ (Fig. 4c) was similar between NDC and AD subjects. Moreover, the
CTF $\beta$ (C99)/CTF $\alpha$ (C83) ratio did not indicate differences between the AD and NDC groups (Fig. 4d).

\section{Lectin-binding analysis of SAPPa and $\triangle A P P \beta$ from brain and $A \beta$-treated cells}

To compare the pattern of brain $\mathrm{sAPP} \alpha$ and $\operatorname{sAPP} \beta$ glycosylation, aliquots of the brain sample extracts were incubated with immobilized Con A and PHA lectins, and SAPP $\alpha$ and SAPP $\beta$ pan-specific antibodies were used to probe the unbound fraction in western blots (Table 1). Since a different cell origin was presumed, we expected to detect differences in the binding properties of the APP-NTF fragments derived from the distinct splice variants. The SAPP $\beta$ species derived from APP695 and APP-KPI displayed differences in binding to both lectins, Con A and PHA (Fig. 5). By contrast, the SAPP $\alpha$ species derived from APP695 and APP-KPI exhibited similar Con $\mathrm{A}$ and PHA binding. 

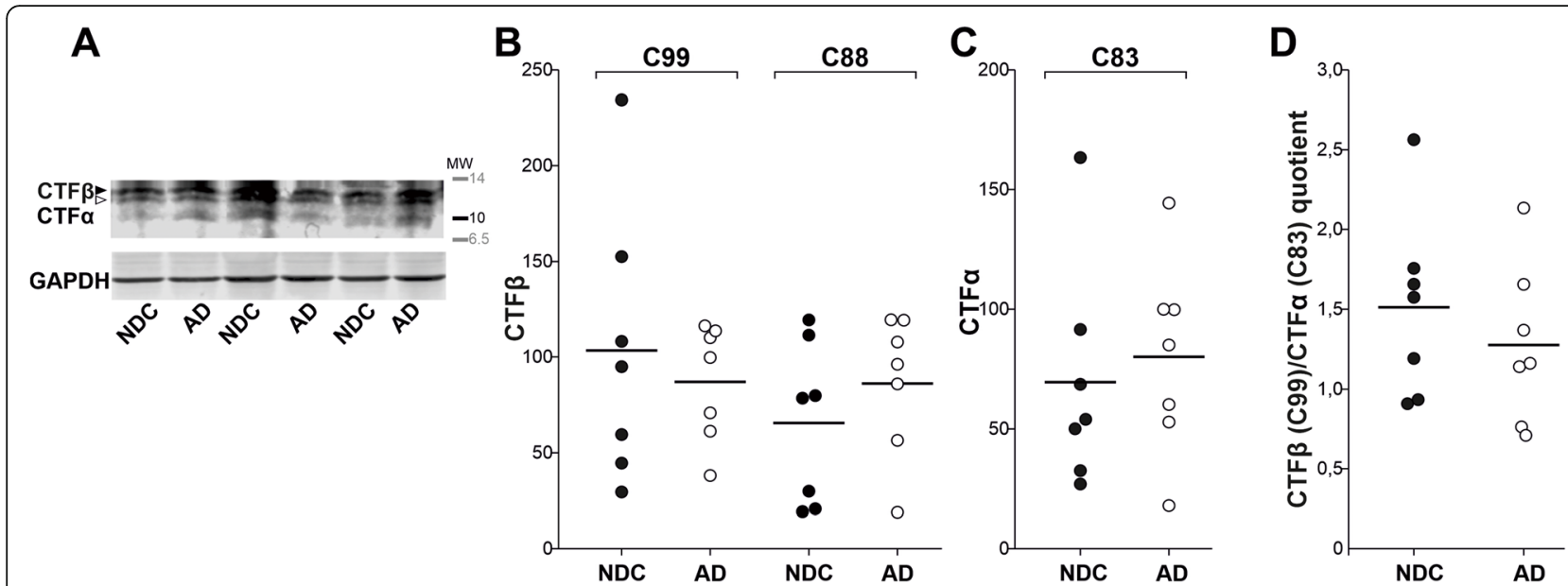

Fig. 4 CTFa and CTF $\beta$ remain unaltered in the AD frontal cortex. a Representative western blots of human frontal cortex tissue from NDC (closed symbol; $n=7$ ) and AD (open symbol; $n=7$ ) subjects probed with a C-terminal antibody (of the full-length APP). Densitometric quantification of the b CTF $\beta$ species, C99 (closed arrowhead) and C88 (open arrowhead) (for characterization see Fig. 1d) or c CTFa (C83), is shown; using GAPDH as a loading control to ensure equivalent amounts of protein were loaded in each lane. The calculations were performed in duplicate. $\mathbf{d}$ Graph of the quotient obtained for each sample by dividing the CTF $\beta$ (C99) immunoreactivity with that for CTFa (C83), for which no statistically significant differences were evident (as was also the case for the CTF quotients not shown: C99/C89; C89/C83)

These data were re-analyzed to compare the lectin affinities between SAPP $\alpha$ and SAPP $\beta$. Interestingly, and in accordance with the differences in molecular mass attributable to glycosylation (Fig. 2c), different patterns of SAPP $\alpha$ and SAPP $\beta$ glycosylation were observed for APP-NTFS derived from either APP695 or APP-KPI (Fig. 6). This suggests that glycosylation determines APP processing by either $\alpha$-secretase either $\beta$-secretase, and this is a common mechanism in neurons and glia. These glycosylation differences between APP-NTFs were observed in both NDC and AD tissue.

Finally, we re-analyzed the data again, this time comparing the glycosylation pattern of each APP-NTF in AD subjects respect to NDC subjects (Fig. 7). There were significant differences in the binding of sAPP $\alpha-695$ to Con A and PHA between the NDC and AD samples, and also for sAPP $\alpha$-KPI binding to Con A. By contrast, there were no significant differences in AD and NDC samples when the proportion of $\mathrm{SAPP} \beta$ that binds to
Con A or PHA was compared, both for species derived from APP695 or from APP-KPI. These differences indicated that APP glycosylation is altered in the AD brain, mainly affecting the APP glycoforms processed by the non-amyloidogenic pathway.

We also examined whether $A \beta$ could be a determining factor in the modulation of sAPP $\alpha$ and SAPP $\beta$ glycosylation in a cellular model that overexpress APP (APP751). CHO-PS70 cells were incubated for 2 days in the presence of $5 \mu \mathrm{M} A \beta 42$ (added to the cells, once a day) or a scrambled $A \beta 42$ peptide, after which the culture media were incubated with immobilized Con A and PHA lectins. The culture media from treated cells were incubated with immobilized Con A and PHA lectins. sAPP $\alpha$ and sAPP $\beta$ were examined in the unbound fraction by western blots, as described above for brain extracts (Table 2). Corroborating that the differences in the molecular mass observed between sAPP $\alpha$ and sAPP $\beta$ species (Supplemental Fig. 2C) are mainly due to differences in their glycosylation, a

Table 1 Glycosylation of sAPPa and SAPP $\beta$ in brain extracts from NDC and AD subjects

\begin{tabular}{|c|c|c|c|c|c|}
\hline \multirow[b]{3}{*}{ Sample } & \multirow[b]{3}{*}{ APP specie } & \multicolumn{4}{|c|}{ \%APP unbound to the lectin } \\
\hline & & \multicolumn{2}{|l|}{ SAPPa } & \multicolumn{2}{|l|}{ SAPP $\beta$} \\
\hline & & Con A & $\mathrm{PHA}$ & Con A & PHA \\
\hline \multirow[t]{2}{*}{ NDC } & APP695 & $12.2 \pm 1.7[7.3-20.6]$ & $6.6 \pm 0.8[4.3-9.4]$ & $2.9 \pm 0.8[0.3-7.1]$ & $2.6 \pm 0.8[0.2-6.8]$ \\
\hline & APP-KPI & $13.7 \pm 2.1[9.2-24.6]$ & $5.7 \pm 0.8[2.8-8.1]$ & $40.4 \pm 4.6[20.2-58.3]$ & $37.0 \pm 3.2[22.6-51.0]$ \\
\hline \multirow[t]{2}{*}{$A D$} & APP695 & $7.0 \pm 1.5[2.4-12.9]$ & $4.0 \pm 0.6[1.8-6.8]$ & $1.2 \pm 0.5[0.1-3.7]$ & $1.9 \pm 0.3[1.0-3.1]$ \\
\hline & APP-KPI & $7.7 \pm 1.3[4.0-12.4]$ & $3.8 \pm 0.6[2.3-5.4]$ & $57.1 \pm 8.5[37.6-89.0]$ & $56.7 \pm 9.7[27.4-95.3]$ \\
\hline
\end{tabular}

The brain extracts from 7 non-demented controls (NDC) and 7 AD patients were incubated with immobilized Con A and PHA lectins. The supernatant recovered that contained the unbound protein was assayed in western blots probed with pan-specific antibodies for sAPPa and sAPP $\beta$ (see Fig. 3 ). The data represent the percentages (mean \pm SEM) and the intervals of the unbound immunoreactivity for SAPPa and sAPP $\beta$. These values were used to compare the differences in lectin binding between the species and groups (see Figs. 5, 6, and 7) 


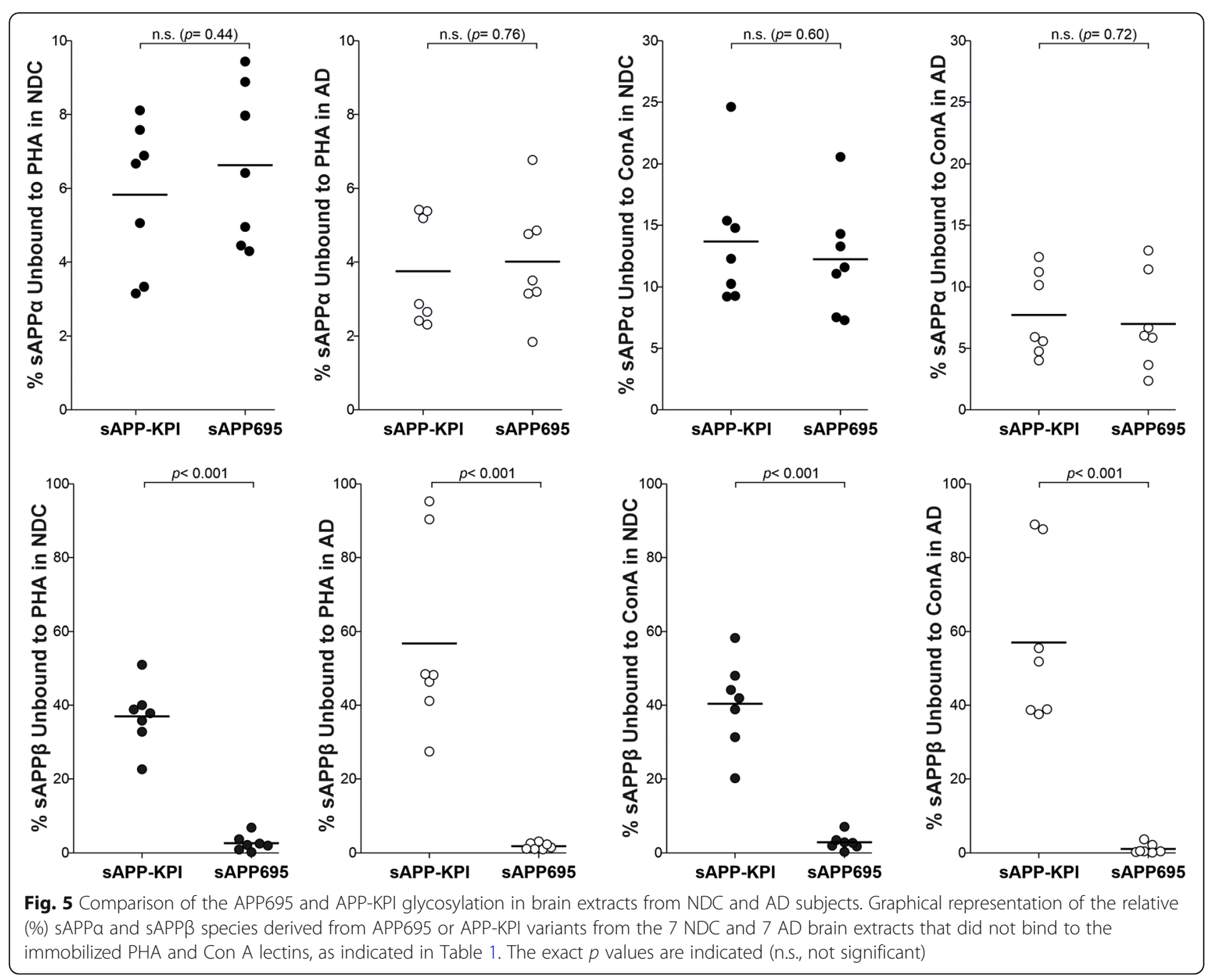

difference in PHA binding was observed between SAPP $\alpha$ and SAPP $\beta$ species in control (scrambled-treated cells). Moreover, and as occurs in the $\mathrm{AD}$ brain, in the cell media from A 342 -treated cells, there was a change in the binding of sAPP $\alpha$ to both lectins, Con A and PHA, when compared to the control cells. The sAPP $\beta$ species from control and A 342 -treated cells also exhibited different binding to Con $\mathrm{A}$ and PHA.

\section{Discussion}

In this study, elevated APP mRNA expression was found in the brain of $\mathrm{AD}$ subjects when compared to control NCD individuals. Several studies have already reported increases in expression of total APP mRNA, both considered as a whole $[14,46]$ and when spliced APP brain isoforms are considered individually [17], particularly the APP-KPI species [37, 50, 64] or APP695 variants [28, 46]. However, as mentioned above, there is contradictory data regarding APP mRNA expression in the brain of $\mathrm{AD}$ patients, with several reports indicating no change or weaker expression $[13,19,30,66]$. Technical issues associated with mRNA extraction from frozen human brain tissue, long post-mortem intervals, or other pre-analytical confounding factors could contribute to these contradictory results. In conclusion, it remains unclear if brain-specific regional and temporal changes occur in the expression of the different APP variants during AD progression.

Since APP is also found in blood cells, assessing the changes in APP mRNA expression in peripheral blood cells from AD patients has been considering an alternative. However, again the quantification of APP mRNA in peripheral blood cells has generated controversial results, with some reports indicating enhanced expression $[29,68]$ and others no changes or even a decrease $[7,24]$ in cells from $\mathrm{AD}$ patients. Interestingly, the changes in protein and mRNA expression in platelets from $\mathrm{AD}$ subjects did not parallel [16]. 


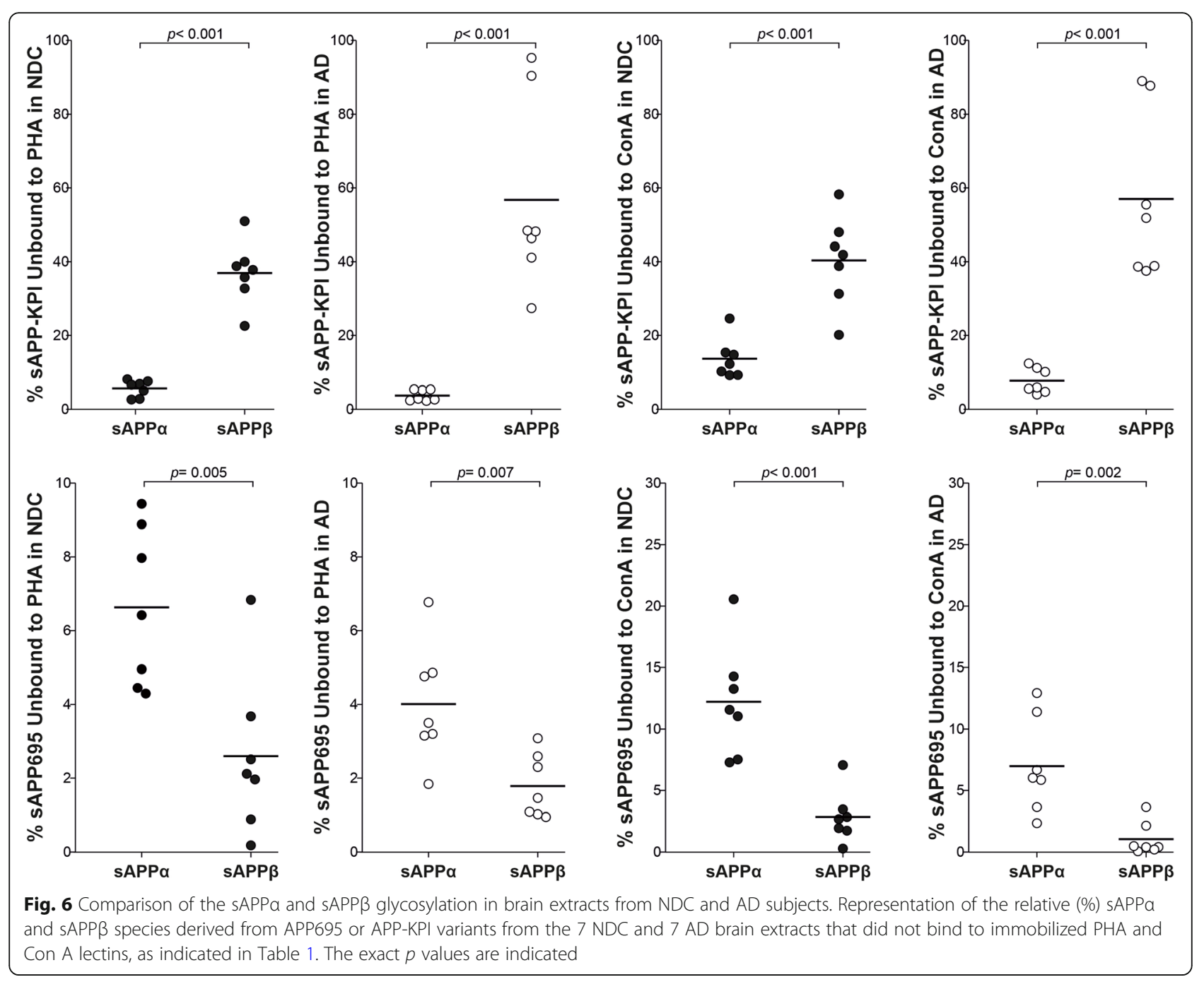

Brain APP protein has been analyzed in only a few studies, probably as it is difficult to interpret the complex pattern of APP variants and fragments. Interestingly, significant increases in APP synthesis and APP-CTF generation were recently demonstrated in neurons derived from AD iPSCs [44]. We previously characterized the sAPP species present in the CSF, which form heteromers involving SAPP $\alpha$, SAPP $\beta$, and also soluble full-length forms of APP. The existence of these heteromers complicates the assessment of specific sAPP species by ELISA [15]. Thus, although western blotting is less well suited to quantitative analysis than ELISA, it is a technique that avoids the interference of APP heteromers. Moreover, our approach allows the sAPP $\alpha$ and SAPP $\beta$ species derived from APP695 and APP-KPI to be studied separately. Here, we found a similar balance of SAPP $\alpha$ and SAPP $\beta$ protein, and of that between CTF $\alpha$ and CTF $\beta$, in brain extracts from $\mathrm{AD}$ and NDC subjects. It was also notable that APP695 and APP-KPI species were only positively correlated when they derived from sAPP $\alpha$ but not from sAPP $\beta$. Interestingly, despite the lack of any differences between NDC and AD patients, the ratio of APP695/APPKPI species was associated with very different profiles of sAPP $\alpha$ and sAPP $\beta$. Our results indicate that relevant amounts of SAPP $\beta$ are likely to be generated in nonneuronal cells and that their pattern of glycosylation may serve to characterize changes in AD. Nevertheless, it should be borne in mind that the normal functions of the different APP isoforms remain unclear.

The levels of APP-CTFs in the human AD brain have not been investigated thoroughly, probably because APP intracellular fragments are quickly processed by $\gamma$-secretase, and/or degraded through autophagy and the endosomal-lysosomal pathway [8, 18, 23]. Moreover, the specificity of the APP-CTF bands in western blots has been recurrently questioned [26]. Here, a parallel analysis of CHO-PS70 extracts treated with the $\gamma$-secretase inhibitor DAPT was performed to identify 


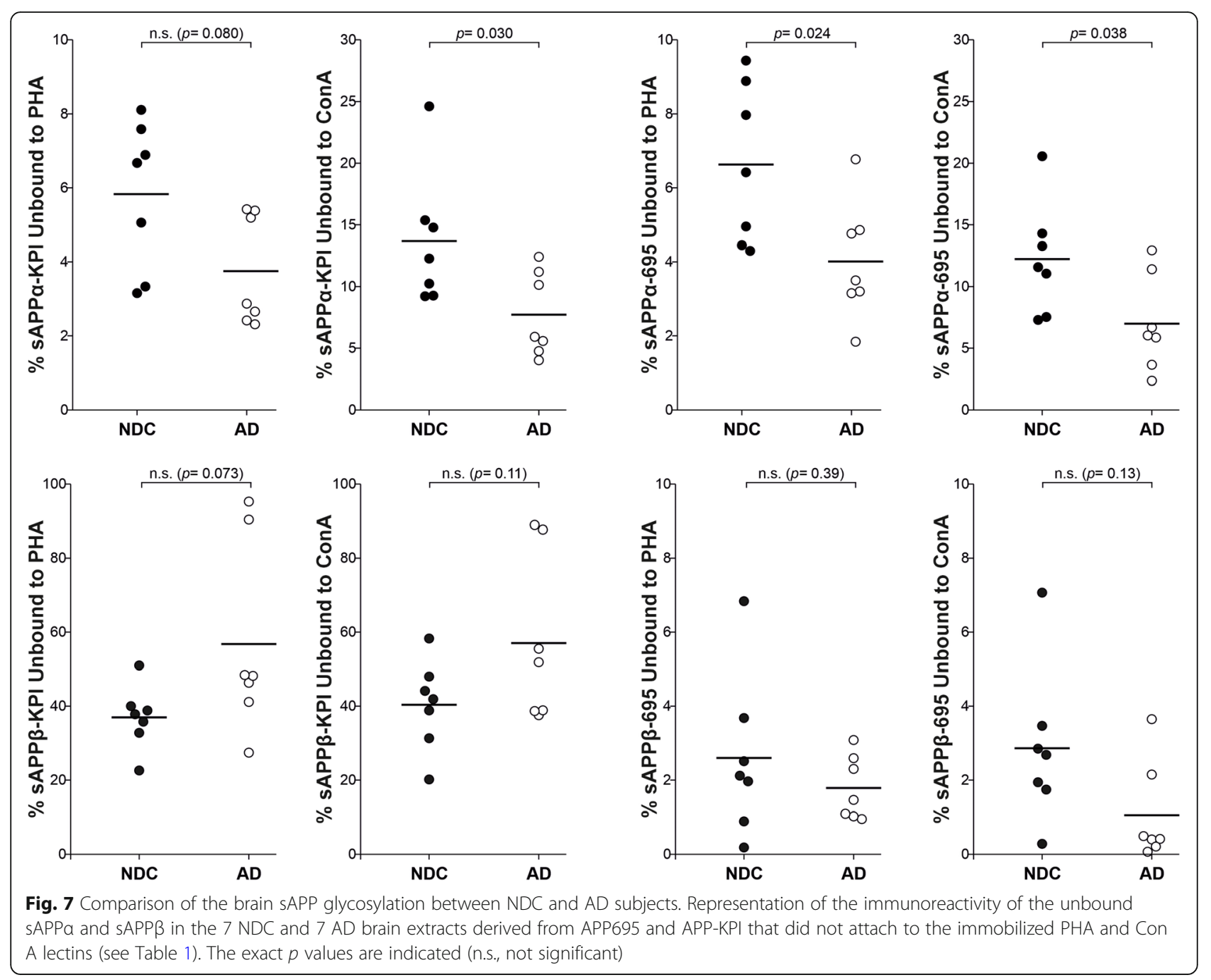

CTF $\alpha$ and CTF $\beta$ in brain extracts. The C-terminal fragments of APP are not affected by alternative splicing, and therefore, they do not serve to distinguish fragments originated from APP695 and APP-KPI. The C-terminal domains of APP are not modified by glycosylation, and thus, the same molecular masses would be expected for these fragments in cell and brain extracts.
We failed to detect any significant differences in the CTF $\alpha$ and CTF $\beta$ in the brain of $A D$ and NDC subjects. In summary, the elevated APP mRNA in AD brains were not paralleled by an increase in the APP fragments assayed.

We cannot rule out whether the changes in transcription are associated with changes in translation, possibly even exerting opposite effects on the final amount of

Table 2 Glycosylation of sAPPa and SAPPB in culture media from CHO-PS70 cell treated with AB42

\begin{tabular}{|c|c|c|c|c|}
\hline \multirow[b]{3}{*}{ CHO-PS70 cell media } & \multicolumn{4}{|c|}{ \%APP unbound to the lectin } \\
\hline & \multicolumn{2}{|l|}{ SAPPa } & \multicolumn{2}{|l|}{ SAPP $\beta$} \\
\hline & $\overline{\operatorname{Con} A}$ & $\mathrm{PHA}$ & Con A & $\mathrm{PHA}$ \\
\hline Control & $41.9 \pm 4.8[26.9-61.8]$ & $62.2 \pm 3.2[51.8-74.2]$ & $57.3 \pm 5.8[40.0-77.1]$ & $75.0 \pm 3.5^{\dagger}[62.6-87.5]$ \\
\hline$A \beta 42$ & $24.7 \pm 2.6^{*}[12.9-30.0]$ & $52.5 \pm 2.4^{*}[44.2-53.3]$ & $28.9 \pm 3.2^{*}[39.0-16.9]$ & $56.6 \pm 3.0^{*}[46.1-68.6]$ \\
\hline
\end{tabular}

The culture media from CHO-PS70 cells (over-expressing APP 751) treated with A 342 or scrambled peptide (control) were incubated with immobilized Con A and PHA lectins. The supernatant recovered containing the unbound protein was evaluated by western blots using with pan-specific antibodies for sAPPa and sAPP $\beta$, similarly that in Table 1. Accordingly, the unbound SAPPa and SAPP $\beta$ were used to compare differences in lectin binding between groups and between sAPP species. The data represent the percentages (mean \pm SEM) and the intervals of the unbound immunoreactivity for sAPPa and SAPP $\beta$, estimated in 8 independent determinations from 2 different experiments

*Significantly different $(p<0.05)$ from the control group

†'Significantly different $(p<0.05)$ from the sAPPa species 
protein. As such, changes in mRNA but not in protein may have a potential impact on disease progression [48]. Indeed, the protein-to-mRNA ratios for many proteins exhibit substantial tissue variability, highlighting the contribution of post-transcriptional regulation in shaping tissue-specific proteomes [21]. Although posttranscriptional regulation of APP mRNAs cannot be ruled out, the fact that the increase in APP mRNA is not mirrored by changes in the APP fragments could be associated with the rapid processing and turnover of this protein [60]. In summary, one of the few general conclusions that can probably be drawn from the different studies of the changes to APP proteolytic fragments in the brain or CSF of AD subjects is that these changes are not expected to be appropriately related to changes in APP brain expression.

The mechanisms that drive APP proteolytic processing and how each alternative pathway is regulated remain to be fully determined. Like many other transmembrane glycoproteins, typically membrane receptors, APP is a substrate of secretases [35]. The proteolytic processing of these receptors is initiated after their binding to membrane-anchored or soluble ligands. However, APP is unlikely to have "canonical" ligands that determine/ regulate its processing by secretases. Anyhow, protein partners that might interact with APP at specific subcellular locations are probably influenced further by proteolytic processing driven by a particular pathway. It is well known that glycosylation influences both the subcellular localization and the protein interactions of glycoproteins. Indeed, increasing evidence indicates that glycosylation plays an important role in regulating the cleavage of APP [65]. Therefore, we explored the glycosylation status of sAPP $\alpha$ and SAPP $\beta$ in the AD brain through lectin binding. To our knowledge, alterations to APP glycosylation in the AD brain have yet to been thoroughly investigated.

The oligosaccharide moieties associated to glycoproteins depend on the specific enzymatic machinery in particular cell types [54] and different isoforms of the same protein may display diverse patterns of glycosylation in the same cell [55]. Indeed, we found different glycosylation patterns for $\mathrm{SAPP} \beta$ species derived from neuronal APP695 and glial APP-KPI variants. More interestingly, we show that the SAPP $\alpha$ and $\mathrm{SAPP} \beta$ originating from the same variants display differences in molecular mass that can be attributed to glycosylation and that these differences produce different lectinbinding patterns. Hence, different APP glycoforms would appear to be processed mainly through different pathways. It was previously indicated that increasing $O-G l c N A c y l a t i o n$ seems to reduce $A \beta$ generation, and it has been considered a promising target for AD drug therapy $[1,3,12,33,53,69]$. Indeed, several $A \beta$ glycopeptides have been identified in human CSF, while the $A \beta 1-38 / 40 / 42$ isoforms appear not to be glycosylated, with an increase of up to 2.5 -fold the Tyr10 glycosylated $A \beta$ peptides in the CSF from AD patients [25]. These data would suggest that sialylated $\mathrm{O}$-glycans may influence APP processing. Hence, the large difference in molecular mass between SAPP $\alpha$ and sAPP $\beta$ detected here indicates that $\mathrm{N}$-glycosylation influences the proteolytic processing of APP and/or its further O-glycosylation.

Our data also demonstrate differences in the glycosylation of the sAPP $\alpha$ species in the AD brain and that $A \beta$ causes altered glycosylation of both sAPP $\alpha$ and $\operatorname{sAPP} \beta$, in a cellular model. Interestingly, altered glycosylation has been demonstrated for several key proteins in $\mathrm{AD}$ (reviewed in [32, 57]). One of the lectins studied here was PHA, which is very specific for bisecting the GlcNAc present in $\mathrm{N}$-glycan structures, indicating alterations in the $\mathrm{N}$-glycan profile in the AD CSF [58]. Hence, there appear to be changes in glycosylation of at least a subset of glycoproteins in the $\mathrm{AD}$ brain at early phases of disease progression.

Moderate changes in the glycosylation of key brain proteins may critically affect their behavior. Alterations to the glycosylation of specific glycoproteins may alter the contribution of different cell types to the protein pool, producing an imbalance in protein glycoforms, and such altered glycosylation may reflect changes in metabolism or in differentiation states. In this context, the altered glycosylation of APP in AD warrants further study, particularly as we assume that APP glycosylation determines its proteolytic processing. As such, alterations to its glycosylation may have pathophysiological consequences in terms of the generation of the diverse APP fragments.

\section{Conclusions}

In summary, this study reveals that there is stronger expression of APP in the AD brain relative to the NDC brain and that there are important particularities in APP glycosylation that possibly affect its processing. Firstly, using lectin binding, we detected changes in glycosylation between sAPP $\beta$ species derived from APP695 and APP-KPI variants, probably reflecting the distinct cellular origin of the variants. More interestingly, differences in glycosylation pattern between SAPP $\alpha$ and SAPP $\beta$ suggest that glycosylation dictates whether the APP is proteolytically processed by the amyloidogenic or the non-amyloidogenic pathway. Furthermore, differences in SAPP $\alpha$ glycoforms between AD and non-disease control tissue indicate altered APP glycosylation in these pathological conditions. Whether altered glycosylation of APP in AD brain could explain the amyloidogenic imbalance remains to be determined. 


\section{Supplementary information}

Supplementary information accompanies this paper at https://doi.org/10. 1186/s13195-020-00664-9.

Additional file 1: Supplemental Figure 1. Increased APP expression in the AD frontal cortex. Relative APP mRNA expression analyzed by qRTPCR in frontal cortex tissue from NDC $(n=7)$ and AD subjects (Braak stage $V-V I, n=7$ ). The total APP transcripts were measured using the specific TaqMan GeneExpression Assay with TaqMan PCR Master Mix. The values were calculated from relative standard curves, normalized to $18 \mathrm{~S}$ from the same cDNA and expressed as the mean \pm SEM: $p<0.001$ relative to NDC as indicated.

Additional file 2: Supplemental Figure 2. Characterization of the APP-NTF and CTF fragments in human frontal cortex extracts. (A) To assess the identity of the SAPPa species derived from the KPI variant, two frontal cortex (Human CX) extracts were analyzed by SDS-PAGE and probed simultaneously with a mouse anti-sAPPa combined with a rabbit anti-KPI. The fluorescence of the secondary antibodies (IRDye 800CW goat anti-rabbit, green; IRDye 680RD goat anti-mouse, red) was detected with the Odyssey CLx Infrared Imaging system (LI-COR), with simultaneous fluorescence (merge) demonstrating co-localization (yellow, arrowhead). $\left({ }^{*}\right)$ Indicates a KPI immunoreactive band that does not co-localize. No similar combination was performed for SAPP $\beta$ species since both the antibodies against SAPP $\beta$ and KPI are generated in rabbit. (B) The frontal cortex extracts and $(\mathbf{C})$ the medium from $\mathrm{CHO}$-PS70 (over-expressing APP751) were subjected to enzymatic deglycosylation (deGlyc), or treated with the vehicle alone as a control (Ctrl), as described in Fig. 2c, and probed simultaneously with the mouse anti-sAPPa combined with a rabbit anti-sAPP $\beta$. The fluorescence of the secondary antibodies (IRDye 800CW goat anti-rabbit, green; IRDye 680RD goat anti-mouse, red) was detected with the Odyssey CLx for simultaneous fluorescence (yellow, merge). (D) Extracts from CHO-PS70 cells treated with the $\mathrm{y}$-secretase inhibitor DAPT or the vehicle alone (control, Ctrl) were probed simultaneously with the rabbit C-terminal antibody common to CTF $\beta$ and CTFa, and the rat antibody $2 \mathrm{D} 8$ raised against the $\mathrm{N}$-terminal domain of $A \beta$ that only detects CTF $\beta$. The fluorescence of the secondary antibodies (IRDye 800CW goat anti-rabbit, green; IRDye 800CW goat anti-rat, red) was detected with the Odyssey CLx, with simultaneous fluorescence (merge) demonstrating co-localization (yellow). The approximate location of the molecular weight (MW) markers is shown.

Additional file 3: Supplemental Figure 3. Correlation of the $\triangle A \beta P P a$ and $S A B P P \beta$ species from human frontal cortex samples. (A) A linear regression analysis was used to assess the correlation between the SAPPa derived from the APP695 and APP-KPI variants, and between the SAPP $\beta$ derived from the APP695 and APP-KPI variants in the brain extracts from controls (NDC: closed symbols, solid lines) and AD patients (open symbols, dotted lines). (B) No correlation emerged from the linear regression analysis between SAPPa and SAPP $\beta$ derived from APP695 variants, or between the SAPPa and SAPP $\beta$ derived from APP-KPI variants. The linear regression coefficient (R) and $p$ values for each correlation are shown (n.s., non-significant $p$ value).

Additional file 4: Supplemental Figure 4. The APP-KPI species remain unaltered in the AD frontal cortex. Representative western blots of human frontal cortex samples from NDC (closed symbol, $n=7$ ) and AD subjects (open symbol, $n=7$ ) probed with an anti-KPI antibody. The densitometric quantification of the species attributed to the $\sim 120 \mathrm{kDa}$ APP-KPI band (arrowhead) is shown. Note that since the anti-KPI antibody cannot distinguish between species with a very similar molecular mass, APP-KPI levels were consider as a whole. Equivalent amounts of protein were loaded in each lane and vinculin was used as a loading control, performing calculations in duplicate. $\left(^{*}\right)$ Indicates a KPI immunoreactive band that does not match with bands detected with anti-sAPPa or SAPP $\beta$ (see Fig. 2b and Supplemental Fig. 2A). The comparison did not identify statistically significant differences between the AD and NDC samples (not even for the $\sim 100 \mathrm{kDa}$ species of uncertain identity: data not shown).

\section{Abbreviations}

APP: Amyloid precursor protein; sAPP: Soluble APP; Aß: $\beta$-amyloid peptide; AD: Alzheimer's disease; Con A: Lectin from Canavalia ensiformis;
CSF: Cerebrospinal fluid; DAPT: N-[N-(3,5-difluorophenacetyl)-l-alanyl]-Sphenylglycine t-butyl ester; DMSO: Dimethyl sulfoxide; CTF: C-terminal fragment; ICD: Intracellular domain; KPI: Kunitz-type serine protease inhibitor; NDC: Non-demented controls; NTF: N-terminal fragment; PHA: Lectin from Phaseolus vulgaris

\section{Acknowledgements}

We thank Drs. C. Haass and M. Willem (Biomedical Center, LudwigMaximilians-University Munich, Munich, Germany) for the generous gift of the 2D8 antibody and Dr. D. Selkoe (Brigham and Women's Hospital, Boston) for providing the CHO-PS70 cells.

\section{Authors' contributions}

ILF, ICl, and JSV were involved with the conception, design, and interpretation of data. CPB, ILF, and ICI performed the experiments. CPB, ILF, $\mathrm{ICl}$, and JSV were involved with data analysis. ILF, ICl, and JSV provided general overall supervision of the study and acquired funding. All authors contributed to the drafting and critical revision of the manuscript and have given final approval of the version to be published.

\section{Funding}

This study was funded in part by the Direcció General d'Universitat, Investigació i Ciència, GVA (AICO/2018/090), Agència Valenciana de la Innovació-Generalitat Valenciana, within the framework of the collaboration agreement (INNCON/2020/8-UCIE Instituto de Neurociencias), and by the Instituto de Salud Carlos III (ISCIII, grants PI15/00665 and PI19-01359), cofinanced by the Fondo Europeo de Desarrollo Regional (FEDER, "Investing in your future"), and through CIBERNED, ISCIII. We also acknowledge financial support from the Spanish Ministerio de Economía y Competitividad, through the "Severo Ochoa" Programme for Centres of Excellence in R\&D (SEV-20170723)

\section{Availability of data and materials}

All data generated or analyzed during this study are included in this published article.

\section{Ethics approval and consent to participate}

This study was approved by the ethics committee at the Miguel Hernandez University (code number\# UMH.iNJS.01.18), and it was carried out in accordance with the Helsinki Declaration regarding research on humans. All human samples were collected from national Brain banks: Banco de Tejidos Neurológicos, Fundación CIEN-Unidad de Investigación Proyecto Alzheimer (UIPA: Madrid, Spain), and the Biobanco en Red de la Región de Murcia (Biobanc-Mur, Murcia, Spain), that obtained informed consent from all patients or their relatives.

\section{Consent for publication}

"Not applicable"

\section{Competing interests}

All the authors who contributed to this work agree with the presented findings. The authors are inventors of a patent submitted for the use of sAPP glycoforms as potential AD biomarkers. The authors have no other competing interests to disclose in connection to this article.

\section{Author details}

${ }^{1}$ Instituto de Neurociencias de Alicante, Universidad Miguel Hernández-CSIC, Av. Ramón y Cajal s/n, E-03550 Sant Joan d'Alacant, Spain. ${ }^{2}$ Centro de Investigación Biomédica en Red sobre Enfermedades Neurodegenerativas (CIBERNED), Sant Joan d'Alacant, Spain. ${ }^{3}$ Instituto de Investigación Sanitaria y Biomédica de Alicante (ISABIAL), Alicante, Spain.

Received: 6 April 2020 Accepted: 3 August 2020

Published online: 12 August 2020

\section{References}

1. Akasaka-Manya K, Kawamura M, Tsumoto H, Saito Y, Tachida Y, Kitazume S, et al. Excess APP O-glycosylation by GalNAc-T6 decreases A $\beta$ production. J Biochem. 2017;161(1):99-111. 
2. Andrew RJ, Kellett KA, Thinakaran G, Hooper NM. A Greek tragedy: the growing complexity of Alzheimer amyloid precursor protein proteolysis. J Biol Chem. 2016;291:19235-44.

3. Ansari SA, Emerald BS. The role of insulin resistance and protein OGlcNAcylation in neurodegeneration. Front Neurosci. 2019;13:473.

4. Arikawa E, Sun Y, Wang J, Zhou Q, Ning B, Dial SL, et al. Cross-platform comparison of SYBR Green real-time PCR with TaqMan PCR, microarrays and other gene expression measurement technologies evaluated in the MicroArray Quality Control (MAQC) study. BMC Genomics. 2008;9:328.

5. Botella-López A, Burgaya F, Gavín R, García-Ayllón MS, Gómez-Tortosa E, Peña-Casanova J, et al. Reelin expression and glycosylation patterns are altered in Alzheimer's disease. Proc Natl Acad Sci U S A. 2006;103:5573-8.

6. Braak H, Braak E. Neuropathological stageing of Alzheimer-related changes. Acta Neuropathol. 1991;82:239-59.

7. Buckland P, Tidmarsh S, Spurlock G, Kaiser F, Yates M, O'Mahony G, et al. Amyloid precursor protein mRNA levels in the mononuclear blood cells of Alzheimer's and Down's patients. Brain Res Mol Brain Res. 1993;18:316-20.

8. Bustos V, Pulina MV, Kelahmetoglu Y, Sinha SC, Gorelick FS, Flajolet M, et al. Bidirectional regulation of $A \beta$ levels by Presenilin 1. Proc Natl Acad Sci U S A. 2017;114(27):7142-7.

9. Buxbaum JD, Thinakaran G, Koliatsos V, O'Callahan J, Slunt HH, Price DL et al. Alzheimer amyloid protein precursor in the rat hippocampus: transport and processing through the perforant path. J Neurosci. 1998;18: 9629-37.

10. Chasseigneaux $S$, Allinquant $B$. Functions of $A \beta, S A P P a$ and $S A P P \beta$ : similarities and differences. J Neurochem. 2012;120(Suppl 1):99-108.

11. Chun YS, Park Y, Oh HG, Kim TW, Yang HO, Park MK, et al. O-GlcNAcylation promotes non-Amyloidogenic processing of amyloid- $\beta$ protein precursor via inhibition of endocytosis from the plasma membrane. J Alzheimers Dis 2015;44:261-75

12. Chun YS, Kwon OH, Chung S. O-GlcNAcylation of amyloid- $\beta$ precursor protein at threonine 576 residue regulates trafficking and processing. Biochem Biophys Res Commun. 2017:490:486-91.

13. Clark AW, Krekoski CA, Parhad IM, Liston D, Julien JP, Hoar DI. Altered expression of genes for amyloid and cytoskeletal proteins in Alzheimer cortex. Ann Neurol. 1989;25(4):331-9.

14. Cohen ML, Golde TE, Usiak MF, Younkin LH, Younkin SG. In situ hybridization of nucleus basalis neurons shows increased beta-amyloid mRNA in Alzheimer disease. Proc Natl Acad Sci U S A. 1988;85:1227-31.

15. Cuchillo-lbañez I, Lopez-Font I, Boix-Amorós A, Brinkmalm G, Blennow K, Molinuevo JL, et al. Heteromers of amyloid precursor protein in cerebrospinal fluid. Mol Neurodegener. 2015;10:2.

16. Di Luca M, Pastorino L, Bianchetti A, Perez J, Vignolo LA, Lenzi GL, et al. Differential level of platelet amyloid beta precursor protein isoforms: an early marker for Alzheimer disease. Arch Neurol. 1998;55:1195-200.

17. Golde TE, Estus S, Usiak M, Younkin LH, Younkin SG. Expression of beta amyloid protein precursor mRNAs: recognition of a novel alternatively spliced form and quantitation in Alzheimer's disease using PCR. Neuron. 1990:4:253-67.

18. Evrard C, Kienlen-Campard P, Coevoet M, Opsomer R, Tasiaux B, Melnyk P, et al. Contribution of the endosomal-lysosomal and proteasomal systems in amyloid- $\beta$ precursor protein derived fragments processing. Front Cell Neurosci. 2018;12:435.

19. Farnsworth B, Peuckert C, Zimmermann B, Jazin E, Kettunen P, Emilsson LS. Gene expression of quaking in sporadic Alzheimer's disease patients is both upregulated and related to expression levels of genes involved in amyloid plaque and neurofibrillary tangle formation. J Alzheimers Dis. 2016;53:209-19.

20. Foveau B, Correia AS, Hébert SS, Rainone S, Potvin O, Kergoat MJ, et al. Stem cell-derived neurons as cellular models of sporadic Alzheimer's disease. J Alzheimers Dis. 2019;67:893-910.

21. Franks A, Airoldi E, Slavov N. Post-transcriptional regulation across human tissues. PLoS Comput Biol. 2017;13:e1005535.

22. Ghiso J, Tagliavini F, Timmers WF, Frangione B. Alzheimer's disease amyloid precursor protein is present in senile plaques and cerebrospinal fluid: immunohistochemical and biochemical characterization. Biochem Biophys Res Commun. 1989;163:430-7.

23. González AE, Muñoz VC, Cavieres VA, Bustamante HA, Cornejo VH, Januário YC, et al. Autophagosomes cooperate in the degradation of intracellular Cterminal fragments of the amyloid precursor protein via the MVB/lysosomal pathway. FASEB J. 2017;31(6):2446-59.
24. Guerreiro C, Silva B, Crespo ÂC, Marques L, Costa S, Timóteo ÂA, et al. Decrease in APP and CP mRNA expression supports impairment of iron export in Alzheimer's disease patients. Biochim Biophys Acta. 2015;1852: 2116-22.

25. Halim A, Brinkmalm G, Rüetschi U, Westman-Brinkmalm A, Portelius E, Zetterberg $\mathrm{H}$, et al. Site-specific characterization of threonine, serine, and tyrosine glycosylations of amyloid precursor protein/amyloid beta-peptides in human cerebrospinal fluid. Proc Natl Acad Sci U S A. 2011;108:11848-53.

26. Haytural H, Lundgren JL, Köse TB, Jordà-Siquier T, Kalcheva M, Seed Ahmed $M$, et al. Non-specific detection of a major Western blotting band in human brain homogenates by a multitude of amyloid precursor protein antibodies. Front Aging Neurosci. 2019;11:273.

27. Jacobsen KT, Iverfeldt K. O-GlcNAcylation increases non-amyloidogenic processing of the amyloid- $\beta$ precursor protein (APP). Biochem Biophys Res Commun. 2011:404(3):882-6.

28. Jacobsen JS, Blume AJ, Vitek MP. Quantitative measurement of alternatively spliced amyloid precursor protein mRNA expression in Alzheimer's disease and normal brain by S1 nuclease protection analysis. Neurobiol Aging. 1991; 12(5):585-92.

29. Jiang S, Zhang M, Ren D, Tang G, Lin S, Qian Y, et al. Enhanced production of amyloid precursor protein mRNA by peripheral mononuclear blood cell in Alzheimer's disease. Am J Med Genet B Neuropsychiatr Genet. 2003;118B: 99-102.

30. Johnson SA, Pasinetti GM, May PC, Ponte PA, Cordell B, Finch CE. Selective reduction of mRNA for the beta-amyloid precursor protein that lacks a Kunitz-type protease inhibitor motif in cortex from Alzheimer brains. Exp Neurol. 1988;102(2):264-8.

31. Kang J, Lemaire HG, Unterbeck A, Salbaum JM, Masters CL, Grzeschik KH, et al. The precursor of Alzheimer's disease amyloid A4 protein resembles a cell-surface receptor. Nature. 1987;325(6106):733-6.

32. Kizuka Y, Kitazume S, Taniguchi N. N-glycan and Alzheimer's disease. Biochim Biophys Acta Gen Subj. 2017;1861(10):2447-54.

33. Kwon OH, Cho YY, Kim TW, Chung S. O-GlcNAcylation of amyloid- $\beta$ protein precursor by insulin signaling reduces amyloid- $\beta$ production. J Alzheimers Dis. 2019;69:1195-211.

34. Liu F, Xu K, Xu Z, de Las RM, Wang C, Li X, et al. The small molecule luteolin inhibits $\mathrm{N}$-acetyl-a-galactosaminyltransferases and reduces mucin-type Oglycosylation of amyloid precursor protein. J Biol Chem. 2017;292(52): 21304-19.

35. Lleó A, Saura CA. $y$-secretase substrates and their implications for drug development in Alzheimer's disease. Curr Top Med Chem. 2011;11(12): 1513-27.

36. Lopez-Font I, Boix CP, Zetterberg H, Blennow K, Sáez-Valero J. Alterations in the balance of amyloid- $\beta$ protein precursor species in the cerebrospinal fluid of Alzheimer's disease patients. J Alzheimers Dis. 2017:57(4):1281-91.

37. Matsui T, Ingelsson M, Fukumoto H, Ramasamy K, Kowa H, Frosch MP, et al. Expression of APP pathway mRNAs and proteins in Alzheimer's disease. Brain Res. 2007;1161:116-23.

38. Menéndez-González M, Pérez-Pinera P, Martínez-Rivera M, Calatayud MT, Blázquez MB. APP processing and the APP-KPI domain involvement in the amyloid cascade. Neurodegener Dis. 2005;2(6):277-83.

39. Mirra SS, Gearing M, McKeel DW Jr, Crain BJ, Hughes JP, van Belle G, et al. Interlaboratory comparison neuropathology assessments in Alzheimer's disease: a study of the Consortium to Establish a Registry of Alzheimer's Disease (CERAD). J Neuropath Exp Neurol. 1994:53:303-15.

40. Moir RD, Lynch T, Bush Al, Whyte S, Henry A, Portbury S, et al. Relative increase in Alzheimer's disease of soluble forms of cerebral Abeta amyloid protein precursor containing the Kunitz protease inhibitory domain. J Biol Chem. 1988;273:5013-9.

41. Nakagawa K, Kitazume S, Oka R, Maruyama K, Saido TC, et al. Sialylation enhances the secretion of neurotoxic amyloid-beta peptides. J Neurochem. 2006:96:924-33.

42. Nakamura N, Kurosaka A. Mucin-type glycosylation as a regulatory factor of amyloid precursor protein processing. J Biochem. 2019;165(3):205-8.

43. Nhan HS, Chiang K, Koo EH. The multifaceted nature of amyloid precursor protein and its proteolytic fragments: friends and foes. Acta Neuropathol. 2015;129(1):1-19.

44. Ochalek A, Mihalik B, Avci HX, Chandrasekaran A, Téglási A, Bock I, et al. Neurons derived from sporadic Alzheimer's disease iPSCs reveal elevated TAU hyperphosphorylation, increased amyloid levels, and GSK3B activation. Alzheimers Res Ther. 2017;9(1):90. 
45. Olsson B, Lautner R, Andreasson U, Öhrfelt A, Portelius E, Bjerke M, et al. CSF and blood biomarkers for the diagnosis of Alzheimer's disease: a systematic review and meta-analysis. Lancet Neurol. 2016;15(7):673-84.

46. Palmert MR, Golde TE, Cohen ML, Kovacs DM, Tanzi RE, Gusella JF, et al. Amyloid protein precursor messenger RNAs: differential expression in Alzheimer's disease. Science. 1988;241(4869):1080-4.

47. Pera M, Alcolea D, Sánchez-Valle R, Guardia-Laguarta C, Colom-Cadena M, Badiola N, et al. Distinct patterns of APP processing in the CNS in autosomal-dominant and sporadic Alzheimer disease. Acta Neuropathol. 2013;125(2):201-13.

48. Perl K, Ushakov K, Pozniak Y, Yizhar-Barnea O, Bhonker Y, Shivatzki S, et al. Reduced changes in protein compared to mRNA levels across nonproliferating tissues. BMC Genomics. 2017;18:305.

49. Perneczky R, Alexopoulos P, Kurz A. Soluble amyloid precursor proteins and secretases as Alzheimer's disease biomarkers. Trends Mol Med. 2014;20(1):8-15.

50. Preece P, Virley DJ, Costandi M, Coombes R, Moss SJ, Mudge AW, et al. Amyloid precursor protein mRNA levels in Alzheimer's disease brain. Brain Res Mol Brain Res. 2004;122(1):1-9.

51. Pulina MV, Hopkins M, Haroutunian V, Greengard P, Bustos V. C99 selectively accumulates in vulnerable neurons in Alzheimer's disease. Alzheimers Dement. 2020;16(2):273-82

52. Russo C, Salis S, Dolcini V, Venezia V, Song XH, Teller JK, et al. Aminoterminal modification and tyrosine phosphorylation of [corrected] carboxyterminal fragments of the amyloid precursor protein in Alzheimer's disease and Down's syndrome brain. Neurobiol Dis. 2001;8(1):173-80.

53. Ryan P, Xu M, Davey AK, Danon JJ, Mellick GD, Kassiou M, et al. O-GICNAC modification protects against protein misfolding and aggregation in neurodegenerative disease. ACS Chem Neurosci. 2019;10:2209-21.

54. Sáez-Valero J, Fodero LR, White AR, Barrow CJ, Small DH. Acetylcholinesterase is increased in mouse neuronal and astrocyte cultures after treatment with beta-amyloid peptides. Brain Res. 2003;965(1-2):283-6

55. Sáez-Valero J, Sberna G, McLean CA, Small DH. Molecular isoform distribution and glycosylation of acetylcholinesterase are altered in brain and cerebrospinal fluid of patients with Alzheimer's disease. J Neurochem. 1999;72(4):1600-8.

56. Sandbrink R, Masters CL, Beyreuther K. APP gene family: unique ageassociated changes in splicing of Alzheimer's betaA4-amyloid protein precursor. Neurobiol Dis. 1994:1:13-24.

57. Schedin-Weiss S, Winblad B, Tjernberg LO. The role of protein glycosylation in Alzheimer disease. FEBS J. 2014:281:46-62.

58. Schedin-Weiss S, Gaunitz S, Sui P, Chen Q, Haslam SM, Blennow K, et al. Glycan biomarkers for Alzheimer disease correlate with T-tau and P-tau in cerebrospinal fluid in subjective cognitive impairment. FEBS J. 2019. https:// doi.org/10.1111/febs.15197.

59. Selkoe DJ, Podlisny MB, Joachim CL, Vickers EA, Lee G, Fritz LC, et al. Betaamyloid precursor protein of Alzheimer disease occurs as 110- to 135kilodalton membrane-associated proteins in neural and nonneural tissues. Proc Natl Acad Sci U S A. 1988;85(19):7341-5.

60. Selkoe DJ, Yamazaki T, Citron M, Podlisny MB, Koo EH, Teplow DB, et al. The role of APP processing and trafficking pathways in the formation of amyloid beta-protein. Ann N Y Acad Sci. 1996;777:57-64.

61. Siegel G, Gerber H, Koch P, Bruestle O, Fraering PC, Rajendran L. The Alzheimer's disease $\gamma$-secretase generates higher 42:40 ratios for $\beta$-amyloid than for p3 peptides. Cell Rep. 2017;19:1967-76.

62. Sogorb-Esteve A, García-Ayllón MS, Llansola M, Felipo V, Blennow K, SáezValero J. Inhibition of $\gamma$-secretase leads to an increase in presenilin-1. Mol Neurobiol. 2018;55(6):5047-58.

63. Tajadini M, Panjehpour M, Javanmard SH. Comparison of SYBR Green and TaqMan methods in quantitative real-time polymerase chain reaction analysis of four adenosine receptor subtypes. Adv Biomed Res. 2014;3:85.

64. Tanaka S, Nakamura S, Ueda K, Kameyama M, Shiojiri S, Takahashi Y, et al. Three types of amyloid protein precursor mRNA in human brain: their differential expression in Alzheimer's disease. Biochem Biophys Res Commun. 1988;157(2):472-9.

65. Tao PF, Huang HC. Regulation of AßPP glycosylation modification and roles of glycosylation on AßPP cleavage in Alzheimer's disease. ACS Chem Neurosci. 2019;10(5):2115-24

66. Tharp WG, Lee YH, Greene SM, Vincellete E, Beach TG, Pratley RE. Measurement of altered A $\beta P P$ isoform expression in frontal cortex of patients with Alzheimer's disease by absolute quantification real-time PCR. Alzheimers Dis. 2012;29(2):449-57.
67. Tomita S, Kirino Y, Suzuki T. Cleavage of Alzheimer's amyloid precursor protein (APP) by secretases occurs after O-glycosylation of APP in the protein secretory pathway. Identification of intracellular compartments in which APP cleavage occurs without using toxic agents that interfere with protein metabolism. J Biol Chem. 1998;273(11):6277-84.

68. Vignini A, Morganti S, Salvolini E, Sartini D, Luzzi S, Fiorini R, et al. Amyloid precursor protein expression is enhanced in human platelets from subjects with Alzheimer's disease and frontotemporal lobar degeneration: a real-time PCR study. Exp Gerontol. 2013:48:1505-8.

69. Wang X, Zhou X, Li G, Zhang Y, Wu Y, Song W. Modifications and trafficking of APP in the pathogenesis of Alzheimer's disease. Front Mol Neurosci. 2017;10:294

70. Weidemann A, König G, Bunke D, Fischer P, Salbaum JM, Masters CL, et al. Identification, biogenesis, and localization of precursors of Alzheimer's disease A4 amyloid protein. Cell. 1989:57:115-26.

71. Willem M, Tahirovic S, Busche MA, Ovsepian SV, Chafai M, Kootar S, et al. nSecretase processing of APP inhibits neuronal activity in the hippocampus. Nature. 2015;526:443-7.

72. Wu G, Sankaranarayanan S, Hsieh SH, Simon AJ, Savage MJ. Decrease in brain soluble amyloid precursor protein $\beta$ (SAPP $\beta$ ) in Alzheimer's disease cortex. J Neurosci Res. 2011;89(6):822-32.

73. Xia W, Zhang J, Kholodenko D, Citron M, Podlisny MB, Teplow DB, et al. Enhanced production and oligomerization of the 42-residue amyloid betaprotein by Chinese hamster ovary cells stably expressing mutant presenilins. J Biol Chem. 1997;272:7977-82.

\section{Publisher's Note}

Springer Nature remains neutral with regard to jurisdictional claims in published maps and institutional affiliations.

Ready to submit your research? Choose BMC and benefit from:

- fast, convenient online submission

- thorough peer review by experienced researchers in your field

- rapid publication on acceptance

- support for research data, including large and complex data types

- gold Open Access which fosters wider collaboration and increased citations

- maximum visibility for your research: over $100 \mathrm{M}$ website views per year

At $\mathrm{BMC}$, research is always in progress.

Learn more biomedcentral.com/submissions 